\title{
List of avian family-group names to be proposed for conservation
}

Walter J. Bock

Department of Biological Sciences, Columbia University, New York NY 10026, U.S.A.

The Standing Committee on Ornithological Nomenclature (SCON) of the International Ornithological Congress has prepared a list of established names of avian family-group taxa (subtribes to superfamilies) and their synonyms as the first step in the process of writing an application to the International Commission on Zoological Nomenclature to stabilise use of these names. The SCON wishes to obtain input from all interested ornithologists and zoologists on this list of avian family-group names and its proposed application to the ICZN. The list is available to all interested ornithologists and zoologists who are willing to examine it carefully and provide the SCON with corrections, additions, comments, and suggestions. This list of avian family-group names is unofficial and should not be used for any purposes other than that just mentioned. Copies of the list may be obtained by writing to Professor Walter J. Bock, Chairperson SCON, at the address above.

\section{Comment on the family name for the storm petrels (Aves) \\ (Case 2024: see BZN 42: 398-400)}

\section{Storrs L. Olson}

Department of Vertebrate Zoology, National Museum of Natural History, Smithsonian Institution, Washington D.C. 20560, U.S.A.

Melville (1985) has performed a good service in reviewing the complicated nomenclatural history of the family names used for the storm petrels and dippers, but I am strongly opposed to his very lengthy and convoluted resolution of the problems involved. Melville proposes to validate HYDROBATIDAE Mathews, 1912, which he correctly emphasises to be doubly invalid, because it is in 'current usage'. His proposal also results in the extremely inconsistent situation wherein a given family includes a subfamily (OCEANITINAE Forbes, 1881) with an older name. My views concerning the undesirability of such practices have been aired recently in this Bulletin and need not be repeated (Olson et al., 1986).

Contrary to Melville, HYDROBATIDAE Mathews is in many quarters not in current usage. Following Brodkorb (1963), many authors, including virtually all avian paleontologists, have adopted the older name OCEANITIDAE Forbes, 1881, and discontinued the use of HYDROBATIDAE because it is clearly invalid (e.g. Condon, 1975; Clancey, 1980; Harrison, 1983; Maclean, 1985; Olson, 1985, and Beehler et al., 1986).

Regardless of how 'current' one or the other name may be, there is still no real justification for sustaining the name HYDROBATIDAE Mathews, 1912, with the curious date citation 1912 (1865), derived from THALASSIDROMIDAE J. W. von Müller, 1865, as Melville proposes in conformance with Article $40 \mathrm{~b}$ of the Code. Because it is based on the always troublesome precept of 'general acceptance', I am not convinced of the wisdom of Article $40 \mathrm{~b}$; why should the Commission in the present case abrogate the much more basic principles established in Articles 23a (Priority) and 52a (Homonymy)? 
Melville's proposals require an arbitrary selection of Articles to be followed and others to be ignored, and he sets forth a long and burdensome list of unnecessary Official and Rejected names as well. The use of the plenary powers to override the basic rules of the Code merely decreases the usefulness of those rules and only leads to ambiguity and uncertainty concerning their proper application.

This particular case illustrates admirably the desirability of simply abiding by the Code, for if authors were only to continue to use OCEANITIDAE, as many do, no action would be required by the Commission, and the literature would not be taxed with additional Official and Rejected names.

\section{References}

Beehler, B. M., Pratt, T. K. \& Zimmermann, D. A. 1986. Birds of New Guinea. 293 pp. Princeton University Press.

Brodkorb, P. 1963. Catalogue of Fossil Birds. Part 1. (Archaeopterygiformes through Ardeiformes). Bulletin of the Florida State Museum, Biological Sciences, 7(4): 179-293.

Clancey, P. A. 1980 (Ed.) Checklist of Southern African Birds. 325 pp. Southern African Ornithological Society.

Condon, H. T. 1975. Checklist of the birds of Australia, Part I. Non-passerines. 311 pp. Royal Australasian Ornithologists' Union.

Harrison, P. 1983. Seabirds, an identification guide. 448 pp. Houghton Mifflin Co., Boston.

Maclean, G. 1985. Roberts' birds of Southern Africa. 5th ed., lii +848 pp. Johan Voelcker Bird Book Fund, Cape Town.

Melville, R. V. 1985. The family names for the storm petrels and the dippers. $B Z N$ 42(4): 398-400.

Olson, S. L. 1985. Early Pliocene Procellariiformes (Aves) from Langebaanweg, South-western Cape Province, South Africa. Annals of the South African Museum, 95(3): 123-145.

Olson, S. L., Rea, A. M. \& Brodkorb, P. 1986. Comment on the proposed grant of precedence to THRESKIORNITHIDAE Richmond, 1917 (Aves) over PLATALEINAE Bonaparte, 1838. BZN 43(1): 12-13. 


\section{$2 \mathrm{BHL}$ Biodiversity Heritage Library}

Bock, Walter Joseph. 1987. "List of avian family-group names to be proposed for conservation." The Bulletin of zoological nomenclature 44, 44-45. https://doi.org/10.5962/bhl.part.261.

View This Item Online: https://www.biodiversitylibrary.org/item/44485

DOI: https://doi.org/10.5962/bhl.part.261

Permalink: https://www.biodiversitylibrary.org/partpdf/261

\section{Holding Institution}

Natural History Museum Library, London

\section{Sponsored by}

Natural History Museum Library, London

\section{Copyright \& Reuse}

Copyright Status: In copyright. Digitized with the permission of the rights holder.

License: http://creativecommons.org/licenses/by-nc-sa/3.0/

Rights: https://biodiversitylibrary.org/permissions

This document was created from content at the Biodiversity Heritage Library, the world's largest open access digital library for biodiversity literature and archives. Visit BHL at https://www.biodiversitylibrary.org. 